\section{Selfie stick: An extension of the photographer's hand in operation room conditions}

Sir,

Digital photography is an extensively used tool for documentation of the clinical presentation of patients and medical and surgical procedures, and it is important from both scientific and medicolegal point of view. Digital photography equipment is easily available and affordable currently.

Best photographs are captured by professional photographers in standard conditions. Medical photographers are professionalists who photograph patients in clinics and operation rooms and aware of sterile procedures. Unfortunately, not every medical facility employs a medical photographer. Shooting a picture intraoperatively can sometimes become a challenge when there is no one but untrained staff available.

Totakepicturesin asterilemedium, gas sterilised underwater camera cases may be used with almost no added infection risk. ${ }^{[1-3]}$ However, we are in the era of smartphones and cameras are used less than they were in the past. We need solutions for smartphones for intraoperative photography.

The surgeon might put on an extra pair of sterile gloves and shoot the picture himself, but in some circumstances, his both hands are busy. When a staff takes picture with a smartphone intraoperatively, he/she puts the sterile drapes at danger by approaching to the surgical site. $\mathrm{He} / \mathrm{she}$ might lose focus or cannot prevent tremor while trying to hold the phone with the arms stretched over the surgical site [Figure 1]. To avoid these problems, we offer a cheap and practical solution. Selfie stick is a monopod that positions the phone beyond the normal range of the arm. It is very cheap, available, and easily used by anyone. After connecting the phone to the device either by bluetooth or by a cable, the stick is extended to the desired length [Figure 2]. The piece that holds the phone is hinged and can be adjusted as desired. The surgeon can direct the staff for best shot. The staff can hold the stick with both hands and lessen the tremor. Thus, we think that selfie stick can be a helpful accessory to take intraoperative pictures without endangering sterile surgical site.

\section{Financial support and sponsorship}

Nil.

\section{Conflicts of interest}

There are no conflicts of interest.

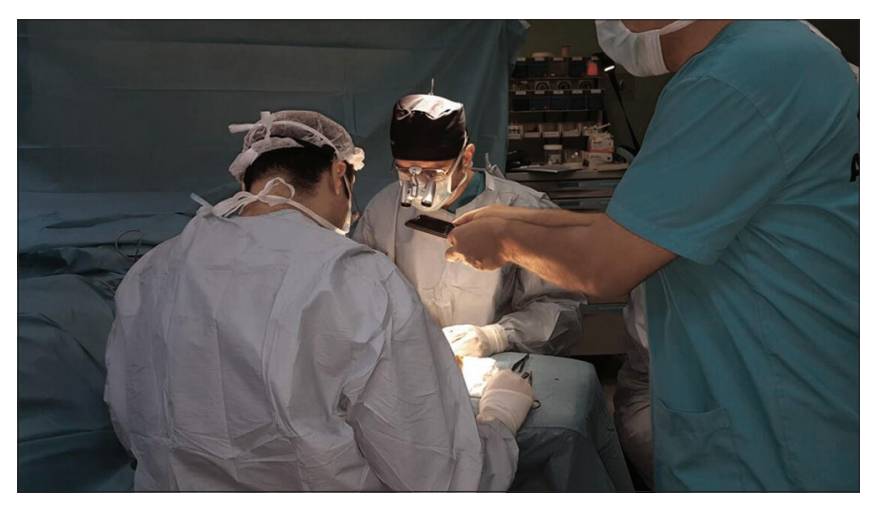

Figure 1: Photograph taken in an ordinary way

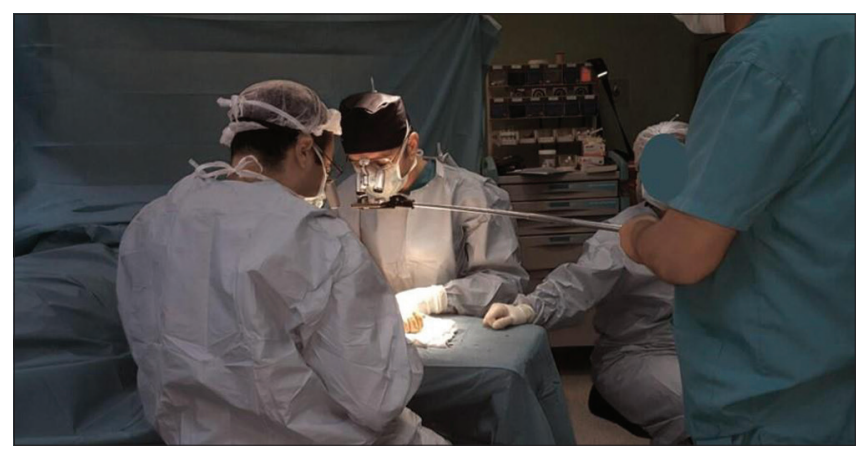

Figure 2: Photograph taken by a selfie stick 


\section{Ayse Sencan, Mehmet Baydar', Kahraman Ozturk', Osman Orman ${ }^{1}$}

Division of Hand Surgery, Bagcilar Teaching and Research Hospital, 'Baltalimani Bone Diseases Teaching and

Research Hospital, Hand Surgery Clinic, Istanbul, Turkey

Address for correspondence:

Dr. Ayse Sencan, Mimar Sinan Caddesi, 6. Sokak, 34000 Bagcilar, Istanbul, Turkey.

E-mail: aysencan35@mynet.com

\section{REFERENCES}

1. Tatlidede S, Egemen O, Bas L. A useful tool for intraoperative photography: underwater camera case. Ann Plast Surg 2008;60:239-40.

2. Raigosa M, Benito-Ruiz J, Fontdevila J, Ballesteros JR. Waterproof camera case for intraoperative photographs. Aesthetic Plast Surg 2008;32:368-70.

3. Tsai J, Liao HT, Wang WK, Lam WL, Kuo LM, Chen RF, et al. A safe and efficient method for intra-operative digital photography using a waterproof case. J Plast Reconstr Aesthet Surg 2011;64:e253-8.

This is an open access article distributed under the terms of the Creative Commons Attribution-NonCommercial-ShareAlike 3.0 License, which allows others to remix, tweak, and build upon the work non-commercially, as long as the author is credited and the new creations are licensed under the identical terms.

\begin{tabular}{|l|l|}
\hline \multicolumn{2}{|c|}{ Access this article online } \\
\hline Quick Response Code: & Website: \\
\hline
\end{tabular}

How to cite this article: Sencan A, Baydar M, Ozturk K, Orman O. Selfie stick: An extension of the photographer's hand in operation room conditions. Indian J Plast Surg 2017;50:115-6.

๑) 2017 Indian Journal of Plastic Surgery | Published by Wolters Kluwer - Medknow 